\title{
Talk dirty to me! Sexblogging som performativ intervention og medieret tilblivelse
}

\section{Af Marie Løntoft}

\section{Abstract}

Talk Dirty To Me. Sex blogging as performative intervention and mediated becoming.

In July 2011 an anonymous blogger began posting small, catchy stories from her personal sex life at Tumblr. Her blog, Sugar Tits, soon developed into a community of young followers posting all kinds of sex related questions, comments and photos of their own bodies. In this article I analyse the 'sex blog' as a digital media as well as 'sex blogging' as a performative practise crossing the divide between offline and online. By focusing on the interactive and participative aspects of Sugar Tits my aim is to trace connections between the digital media of the blog and the materiality of the sexed and sexualised body: How does the formal structure and interactive functions of Sugar Tits construct the body? And how does this collective, online mediation of the intimate body interfere with the offline bodies and desires of the participating followers? These questions are addressed within a framework of theories of performance and performativity as well as poststructuralist feminist thinking concerning the materiality of the body. In the end I consider the feminist potential of the sexual 'blog body' suggesting that Sugar Tits may be considered a feminist figuration of collective subjectivity. 
"Last spring I had a particularly disgusting sexual exploit with a guy I picked up at a bar who made me put dildos in his ass. I thought it a shame I couldn't write about it on my first blog so I just decided to start a new "anonymous" one devoted to sex."

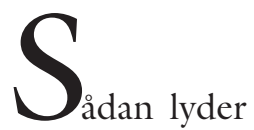
den amerikansk-kroatiske blogger og selverklærede feminist 'Sugar Tits' (herefter ST) egen bramfri udlægning af baggrunden bag lovesugartits.tumblr.com. ${ }^{2} \mathrm{Og}$ da en forvirret besøgende på siden spørger "Seriously, what is this all about??", får han svaret "just a place to show off my butt ;-)" med et karakteristisk selvironisk glimt i øjet. Sarkasmen og idealismen, det frast $\varnothing-$ dende og det lystfyldte, det hudløst ærlige og det hårdt iscenesatte går hånd $\mathrm{i}$ hånd $\mathrm{i}$ ST's virtuelle sexperformance. I begyndelsen består bloggen ganske vist mest af autobiografiske fortællinger fra et slutty singleliv samt hovedløse selfies af den anonyme jegfortællers nøgent poserende krop. Men i løbet af de snart tre år bloggen har eksisteret, har den imidlertid udviklet sig til meget mere end intime bekendelser og seksuel selviscenesættelse - ikke mindst via læsernes omfattende bidrag til og interaktion med bloggeren og med hinanden.

Det er især disse relationelle og kollektive aspekter af sexbloggen, jeg interesserer mig for i denne artikel. Den beskedne akademiske litteratur om kvinders sexblogs fokuserer primært på individuel bekendelse, autenticitet og bevidstgørelse. Med min analyse af Sugar Tits vil jeg i stedet kaste lys over de performative, interaktive og participatoriske aspekter af sexbloggens virkemåder. Jeg undersøger derfor i højere grad sexbloggens kropslige og kollektive begivenhedskarakter end dens narrative funktioner. Ved at fokusere på, hvordan bloggen gør, frem for hvad den siger, bliver det muligt at undersøge forbindelsen mellem selve det digitale medie, sexbloggens formelle struktur og 'værkkarakter' og den kønskrop, der konstrueres og aktiveres heri.

Gennem disse koblinger ønsker jeg at indkredse nogle processuelle aspekter af de digitale mediers potentiale i forhold til den kønnede og seksualiserede krop. Med sexbloggens eksponering af kropslige handlinger og affekt og dens aktivering af fysisk og emotionel intensitet, opstår vidtrækkende deltagelsesformer, der overskrider grænserne mellem offline og online og mellem krop og medie. Samtidig tilbyder bloggens fortløbende, hybride mediering af kønskroppen nye rammer for at tænke krop og processuel materialitet, samt, i forlængelse heraf, at overveje den intime krops mulige agens i kollektive forandringsprocesser. Kan bloggen som digitalt medie og sexblogging som performativ praksis iværksætte den seksuelle krop som et potentielt feministisk virkefelt?

Med et kønsfilosofisk afsæt i Judith Butlers og Rosi Braidottis forskellige konceptualiseringer af kroppen som en aldrig færdig proces, forsøger jeg i det følgende at indkredse Sugar Tits performative, interaktive og participatoriske iværksættelse af en processuel og relationel kropsmaterialitet. I analysen bevæger jeg mig gennem tre forskellige niveauer: bloggen som online/offline performance, som hypertekstuelt netværk og som kollektiv begivenhed. Til slut opsummerer jeg mere samlet relationerne mellem krop og blog og overvejer sexbloggens aktivistiske og transformatoriske potentiale. Men først en kort introduktion til fænomenet sexblogging og nogle af dets køns- og seksualpolitiske implikationer.

\section{AT BLOGGE SIT SEXLIV}

Når Sugar Tits opretter en personlig blog "devoted to sex" tager hun del i en digital praksis, der er stærkt domineret af kvinder (Attwood 2009:6). I løbet af de seneste ti år har sexblogging vundet stort indpas $\mathrm{i}$ subkulturelle cirkler såvel som i mainstream 
webkultur - fra cyberfeministiske netværk og queer pornoaktivisme til de store netavisers livsstilssektioner og digitale damebladsklummer. Anonyme, selvbiografiske sexblogs som britiske Girl With a One Track Mind og Belle du Jour har făet bred, offentlig opmærksomhed og er efterfølgende blevet udgivet som storsælgende 'blooks' (Attwood 2009). Hele konferencer for kvindelige sexbloggere er opstået i USA og England, ${ }^{3}$ og projekter som The NYC Sex Bloggers Calender, hvor overskuddet går til oplysning om sexarbejderes rettigheder, er blevet en succes. En af initiativtagerne til sidstnævnte er forfatter og sexrettighedsaktivist Audacia Ray, som, udover selv at skrive den personlige sexblog Waking Vixen, også har publiceret en af de få samlede fremstillinger af kvinders sexblogging som cyberkulturelt og seksualpolitisk fænomen (Ray 2007).

Blogmediets tilgængelighed, dagbogslignende publiceringsformat og mulighed for anonymitet har altså gjort det til vor tids oplagte platform for seksuel bekendelse og selvrefleksion. Samtidig tilføjer muligheden for læserkommentarer, links mm. et seksualpolitisk eller aktivistisk potentiale for netværksopbygning og erfaringsudveksling. Dette har fået psykologer til at foreslå, at kvinders sexblogs kan "help develop vocabularies of desire, reduce shame, and build communities enabling women to continue this process of regaining control over information about sexuality" (Wood 2008:1). I den henseende kan fænomenet ses som en digital fortsættelse af andenbølgefeminismens basisgrupper og det feministiske potentiale som en art "consciousnessraising 2.0" (Wood 2008:1). Andre har fremhævet blogformatets særlige kombination af "confessionel description and critical reflection" (Downing 2012: 6) i fremstillingen af kvindelig seksualitet - to forskellige diskurser, som nemlig, ifølge Downing, ellers er blevet associeret med hver sin feministiske fløj i 80'ernes 'Sex Wars'. Her kæmpede liberale 'prosex-feminister' for skabelsen af seksu- elle subjektpositioner og individuel nydelse, mens mere systemkritiske 'antiporno-feminister' kritiserede patriarkatets seksualiserede magtdynamikker og objektgørelse af kvindekroppen (se Downing 2012: 3ff, Barker\&Gill 2012: 3ff). I de nye sexblogs ser Downing "a co-existence of confession of individual erotic pleasure and critique of systemic iniquity" (Downing 2012:5). Herved kan sexblogging måske også bidrage til en genforhandling af seksualpolitiske positioner samt en nuancering af aktuelle diskussioner om seksualisering og medier, internetporno mm. ${ }^{4}$

De mediemæssige og kønsmæssige implikationer af kvinders sexblogging synes altså primært at blive koblet sammen med blogmediets narrative og deskriptive funktioner; sproglig artikulation, bekendelse, selvrefleksion, vidensdeling, bevidstgørelse. I denne optik mangler imidlertid, for mig at se, en vigtig adressering af selve den fysiske, seksuelle (kvinde)krop, der er bloggenes direkte og indirekte omdrejningspunkt: Når man blogger sit sexliv, blogger man også sin krop. Hvordan konstrueres denne seksuelle blogkrop, og hvordan virker den tilbage på de materielle kroppe (bloggerens såvel som læsernes) uden for skærmen? Med disse spørgsmål indskriver sexblogging sig i teoretiske diskussioner om kroppen i cyberspace såvel som i en kønsfilosofisk diskussion om betydningen og virkningen af kroppens kønsspecifikke materialitet.

\section{KROPPEN SOM PROCES}

Kroppens materialitet har været en afgørende udfordring for moderne kønsteori. Den biologiske krop er ofte blevet anført som en form for smertegrænse for de sociale og diskursive kønskonstruktioner. Med Judith Butlers Gender Trouble fra 1990 blev denne smertegrænse brudt. Heri teoretiserer Butler nemlig ikke blot det sociokulturelle 'gender', men også det biologiske 'sex' som en diskursiv effekt af kulturelle normer for genkendelig kønsidentitet. Butlers teori om 
det performative køn er derfor ofte blevet fremstillet som den endelige afskrivning af den fysiske kønskrops betydning. Imidlertid kan den performative vending i de konstruktionistiske kønsopfattelser også ses som en genindskrivning af kropsmaterialiteten i moderne feministisk tænkning og praksis, idet den sætter fokus på kroppenes aktive gøren og aldrig afsluttede materialiseringsprocesser.

Fra et andet teoretisk udgangspunkt leverer den italienske filosof Rosi Braidotti ligeledes et bud på en feministisk teoretisering af kroppen som uafsluttet proces frem for stabil væren. Med inspiration fra Gilles Deleuze forstår Braidotti kropsmaterialiteten og det kropsligt kønnede subjekt som en nomadisk, relationel tilblivelsesproces. Butlers og Braidottis uenigheder til trods, 5 muliggør de tilsammen en mere nuanceret forståelse af en kønskrop, hvis konkrete versioner og forekomster aldrig er essentielle eller endelige, men altid 'in the making'; $i$ færd med at tage form eller blive til. I forhold til Sugar Tits' begærende og begxrede kroppe bliver spørgsmålet altså, hvordan sexblogging som digital og performativ praksis spiller sammen med disse kropslige materialiserings- og/eller tilblivelsesprocesser.

Ifølge Butler formes den fysiske kønskrop via gentagne ytringer og handlinger, der uundgåeligt citerer hegemoniske, kønsspecifikke normer. Materiens tilsynekomst som morfologisk enhed, dvs. genkendelig kvinde- eller mandekrop, er således en effekt af de kulturelle diskurser, der betinger vores talehandlinger såvel som vores "bodily gestures, movements, and styles of various kinds" (Butler 2007: 191). Med sproget afgrænser (og dermed former) vi den krop, vi benævner, og med fysiske praksisser fremfører vi den som kønsspecifikke "styles of flesh", indskrevet i kulturelle tolkningsrammer og derfor "never fully self-styled" (ibid: 190). Denne stilisering af kønskroppen producerer en iterativ materialisering af diskurserne om den. Kropsmaterialiteten må således, hos Butler, forstås som noget, der løbende aflejres, versioneres og stabiliseres som form.

Hos Braidotti tænkes kønskroppen ikke så meget som afgrænset enhed eller form, men mere som situering og relation. Med inspiration fra henholdsvis Luce Irigaray og Gilles Deleuze fremskriver Braidotti således den kønnede krop som en bevægelig konstitution af samvirkende, kropsliggjorte forskelsrelationer "between men and women", "among women" og "within each women" (Braidotti 2011: 151). Mens de to første niveauer kan siges at vedrøre kroppen som henholdsvis representation (andetgjort objekt) og erfaring (forskelligt situerede, virkelige kvindekroppe), så ser jeg det tredje niveau, det Braidotti kalder "sexual difference level 3" (ibid.: 157ff), som kroppens og subjektets fysiske og affektive sammensathed; de uforudsigelige impulser og modsætningsfyldte passioner, som hver enkelt kvindekrop gennemstrømmes af. Kroppens materielle tilblivelse finder, ifølge Braidotti, sted i konstante skift mellem disse niveauer, som "a substream of living matter endowed with memory and capable of multiple variations" (ibid.: 158). Det er altså den processuelle krop forstået som rhizomatisk ${ }^{6}$ og affektiv tilblivelse frem for diskursivt afgrænset materialisering.

Overordnet kan Butlers og Braidottis to forskellige perspektiver indkredses som henholdsvis materialitet som performativitet og praksis og materialitet som relation og netverk (jf. Damsholt, Simonsen \& Mordhorst 2009:30ff). Således begrebsliggør Butler en performativ kropsmaterialitet, der, kontinuerligt og gennem forskellige praksisser, aflejres, afgrænses og stabiliseres som genkendelig form. Heroverfor betoner Braidotti en relationel materialitet bestående af molekylære bevægelser eller netværk, hvori kroppe udgør "collections of disparate flows, materials, impulses, intensities, and practices" (Currier 2010: 264). I denne deleuzianske optik udgør kønskroppen en 'relationel effekt' af sammensatte og 
sammenfiltrede betydningsfelter frem for en morfologisk totalitet.

Med disse to perspektiver bliver det muligt at forstå flere forskellige niveauer af $\mathrm{Su}^{\text {- }}$ gar Tits' radikalt kønnede, seksualiserede kroppe. For det første synes Butlers og Braidottis begreber at betone hvert sit aspekt af de digitale mediers processuelle - performative og relationelle - funktionsmåde og tilsvarende mediering af kroppen. Mens Butler især kan belyse bloggens stiliserede kropsfremførelser og diskursive citeringsmekanismer, indfanger Braidottis perspektiv bedre effekterne af det hybride, kollektive netværk og de interaktive relationer, som blogmediet genererer. For det andet fremhæver de to perspektiver forskellige dynamikker og potentialer vedrørende den seksuelle krop. Her kan Butlers perspektiv især synliggøre seksualiteten som stiliserende og dermed formgivende performativ praksis, mens Braidotti snarere synes at betone begæret og de seksuelle relationer som formopløsende selvoverskridelse. Og endelig muliggør henholdsvis et performativt og et relationelt materialitetsbegreb to forskellige bud på feministiske forandringsprocesser, der hverken negligerer eller determinerer kropslige erfaringer og praksisser: Mens Butler peger på gentagelsens potentiale for kritisk-subversive forskydninger af den kropsmaterialiserede norm, betoner Braidotti det kropsligt-affektive potentiale for affirmative, transformerende tilblivelser. Sugar Tits' iværksættelse af disse performative og relationelle kropsmaterialiteter må netop eftersøges i bloggens mediespecifikke formsprog og funktionsmåde.

\section{SUGAR TITS: IT'S ME ONLY FACELESS}

Sugar Tits er en såkaldt tumleblog. Tumblr er en multimedial mikroblogging-platform og samtidig et socialt netværksmedie, der giver brugerne mulighed for at dele tekst, billeder og video, give likes til eller reblogge hinandens indlæg. Desuden har Tumblr en integreret spørgefunktion, hvorigennem besøgende anonymt kan stille spørgsmål eller komme med kommentarer, som blogindehaveren så efter eget valg kan publicere og besvare. Som digitalt tekstformat kan Tumblr siges at befinde sig mellem en traditionel blog og en Twitter-profil. Således også hos ST, der veksler mellem jævnlige publiceringer af længere, gennemskrevne tekster (tagget stories) og korte her-og-nuagtige 'live-opdateringer'. Hertil kommer de mange anonyme spørgsmål/svar, fotos $\mathrm{mm}$., som publiceres løbende, ofte time for time. På bloggens simple, fluffy-lyserøde forside optræder de forskellige slags poster ukategoriseret under hinanden i den vertikale blogrulles omvendte kronologi. Klikker man på “archive” i øverste højre hjørne făr man i stedet en fortættet, horisontal kollage af blogposternes skrift- og billedfragtmenter måned for måned. Med den øgede mængde af brugergenereret tekstog billedmateriale samt rebloggede, feministiske citater, sexfotos og animationer danner Sugar Tits' blogarkiv en slags kollektiv, multimedial montage af kroppe og stemmer, fantasier, erfaringer og statements.

Bloggens konkrete indhold udgøres altså af tekstuelle og visuelle elementer med forskellige afsendere. Men en personlig blog er ikke kun en fortløbende online publicering af digitalt materiale. At blogge er i høj grad også en praksis med performative, interaktive og participatoriske aspekter, der omfatter det levede liv - kroppe, handlinger og relationer - uden for bloggen. Dette aspekt radikaliseres i sexbloggens tilfælde. Når ST begynder at genfortælle sine sexoplevelser online, påbegynder hun således også en slags performance, der inddrager hendes virkelige sexliv. Men hvad sker der i denne performance, når sex bliver til 'stories' og krop bliver til blog?

I første omgang synes der at være tale om en tilsyneladende traditionelt mimetisk eller dokumentarisk relation mellem virkelighed og repræsentation: Bloggerens private sexliv danner det autobiografiske forlæg for bloggens tekster. Når en læser efterspør- 
ger flere intime historier svarer ST, at der pt. ikke rigtig sker noget $\mathrm{i}$ hendes sexliv, hvorfor hun ikke har noget at fortælle. Og når en anden læser spørger, om hun bruger en diktafon til at optage samtalerne med sine elskere for at kunne gengive dem på bloggen, svarer hun: "LOLZ, I'm not that creepy! I just have a super good memory" (Sugar Tits, 29.05.2011). Der insisteres altså umiddelbart på bloggens en-til-enrelation til virkeligheden og på et kausalt hierarki mellem begivenhed og dokumentation: Hvad der fortelles online er, hvad der skete offline. Ingen sex, ingen tekst.

I denne autobiografiske optik lokaliseres sexbloggens 'egentlige' handlinger og begivenheder implicit i et offline 'live-domæne', som blogmediet blot dokumenterer. Men som medieteoretikeren Phillip Auslander har påpeget, er dokumentationen altid også en performance i sig selv: "the act of documenting an event as a performance is what constitutes it as such" (Auslander 2008:5). Derfor giver det for Auslander heller ikke mening at skelne mellem en live-begivenhed og dens genfortælling. ST's kropslige handlinger får, i Auslanders optik, deres virkning og betydning, selve deres begivenhedsmæssige liveness og performative effekt, $i$ kraft af bloggens genfortællende mediering. Og samtidig udgør også selve medieringen en begivenhed med sin egen form for online 'liveness' i den processuelle publicering. Det at poste en fortxlling om en seksuel handling er en seksuel handling. ST's sexblogging kan således forstås som en performativ praksis på to forskellige niveauer: For det første gør det at dokumentere og genfortælle de private seksuelle handlinger dem til en form for løbende kropslig performance, der udspiller sig offline. For det andet udgør selve medieringen, de løbende handlinger, ytringer og interaktioner $p a ̊$ bloggen, i sig selv en online performance.

Forbindelsen mellem begivenhed og genfortælling, handling og tekst, er altså langt fra nogen mimetisk envejsrelation. At den kropslige virkelighed ikke bare er autentisk forlæg for bloggens tekster, men i lige så høj grad et produkt heraf, bliver helt konkret, når ST besvarer en ny efterspørgsel om flere bloghistorier således: "I plan on going out alone this week to see if I can catch some tail" ( Sugar Tits, 27.04.2011). Her eksponerer bloggen så at sige de materielle effekter af sin egen diskurs; omvendingen i det kausale forhold mellem sex og stories. Samtidig italesættes en forestående seksuel performance, som fysisk finder sted på en eller anden bar i Milano, men som også allerede udspiller sig i bloggens kollektive reiteration og dermed synes at udgøre en simultan online performance, idet læserne gøres til vidner allerede før en evt. nedskrivning. Med kunsthistorikeren Rebecca Schneiders ord er dokumentationens para-doksale forhold nemlig, at "the site of the event is in the witnessing, the re-telling / re-seing, not in the 'event' itself; and yet the 'event itself' becomes what is told in retelling" (Schneider, 42).

Schneiders forskydning af det performative moment fra begivenhed til genfortælling indikerer altså en forskydning af Sugar Tits' kropslige realitet fra det materielle til det diskursive og fra det afsluttede til det uafsluttede. Herigennem synes bloggens genfortællings effekt at bygge på en Butlersk idé om performativitet som "the vehicle through which ontological effects are established" (Butler 1994: 17). De kropslige begivenheder såvel som det autentiske jeg 'bag' Sugar Tits udgør, i dette lys, en performativ effekt af bloggens diskursive maskineri frem for at være dens præ-eksisterende, offline fundament. Her virker anonymiteten tvetydig, idet den kan være en garant for de intime bekendelsers oprigtighed, samtidig med at selve pseudonymet "Sugar Tits" tydeliggør bloggeren som en online-persona, der skabes på bloggen.

Tilsvarende markerer de nøgne, hovedløse selvportrætter, der supplerer ST's sexfortællinger, en tvetydig forbindelse mellem offline- og online-jeg og -krop: Den frem- 
viste krop tilbyder sig som konkret, visualiseret ophav til historiernes fysiske handlinger og som den stabile offline forankring af det bloggende subjekt: "It's me only faceless", som ST selv formulerer det. Men dette materielle "me", fotografiernes iscenesatte objekt, er netop "faceless" i helt konkret forstand; en depersonificeret materialitet, der stiliseres og versioneres post efter post. De løbende afbildninger af den samme, hvide, tynde krop lægger sig som materielle citater i arkivets hypertekst og fremviser bloggens kropslige "me" som en iterativ seksuel stiliseringsproces, "at once intentional and performative” (Butler 2006:190).

At denne performative blogkrop opføres i et felt af kollektive betydninger, bliver tydeligt, når ST begynder at interagere med sine læsere.

\section{OVERSHARING OG DIRTY TALK}

Godt halvanden måned efter bloggens oprettelse, inviteres læsernes kroppe med ind $\mathrm{i}$ Sugar Tits hypertekstuelle korpus:

I just opened my ask box (didn't realize it was closed) - if yall wanna harass me, ask me gross questions or tell me about your buttholes or pooping in people's mouthes or pissing or choking or any other romantic shit, please do and I'll make it super public and embarrassing (Sugar Tits: 27. juli 2011)

Den voksende skare af followers har i høj grad lyst til at stille intime spørgsmål til deres "Sugar Mama", som hun bliver døbt, og til at dele alt fra kropsåbninger til "romantic shit” på bloggen. I første omgang er der mest tale om konkrete sex- og kropsrelaterede spørgsmål, men efterhånden udvider læserbidragene sig til en mere alsidig udveksling af usikkerheder og nysgerrigheder omkring krop og begær, identitet og relationer, kønsroller og seksualmoral. Tonen $\mathrm{i}$ ovenstående opfordring er hård og sarkastisk, og spørgeknappen omdøbes i Sugar Tits til "Talk Dirty to Me". Men den hardcore attitude bliver $\mathrm{i}$ vid udstrækning mødt af følsomme og usikre stemmer og mere sårbare kropsligheder. Mens ST kan fremstå kynisk eller decideret destruktiv i sine egne selvudleveringer, forvandler hun sig i mødet med sine læsere til en særdeles omsorgsfuld og rummelig karakter. Hun svarer med ømhed og humor på alt fra praktiske problemer med analsex og intimbarbering til fortvivlede bekendelser om forbudte fantasier og seksuelle skamfølelser. Med disse sproglige interaktioner forandres bloggens stemme radikalt og en mangfoldighed af kropsligt-intime erfaringsfelter flyder ind over hinanden.

Parallelt hermed udvikler relationerne i selve blogteksten sig i mere kollektiv retning, idet læserne begynder at svare og kommentere på hinandens spørgsmål og situationer. Da det ikke er muligt at kommentere direkte på andre læseres indlæg, foregår denne bruger-til-bruger-kommunikation med ST som publicerende moderator og medierende bindeled. Indforståede opfølgninger og bidrag indledt med "To the annon who wrote that.." fletter sig således ind i hyperteksten, sideordnet med og opbrudt af aktuelle opdateringer, pornobilleder, nye sexspørgsmål mm. Resultatet bliver et decentralt, ikke-hierarkisk tekstkorpus med mange stemmer, der taler i munden på og til hinanden gennem ST. Bloggeren bliver en slags instans, som brugerne ikke kun henvender sig til, men også henvender sig igennem.

Hertil kommer de fotografiske submissions, som læserne begynder at uploade af egne, afklædte kroppe. Umiddelbart kopierer disse ST's eksempel: Læserne mimer de konkrete kropslige positioner, de hjemlige settings og den ofte underspillede seksuelle attitude såvel som selve den performative handling, publiceringen udgør. Deres selvportrætter bliver et slags svar på, men også en kontinuerlig forskydning af ST's selvportrætter og den kropslige norm, de citerer. Heller ikke en krop kan nemlig gentage uden fejlmargen: "bodies never quite com- 
ply with the norms by which their materialization is impelled" (Butler 1993: 2).Når ST's “style of flesh" gentages i en anden krop, i andre materielle og affektive kontekster, produceres derfor andre betydninger i den kollektive hypertekst, men potentielt også individuelle' rematerialiseringer' af bloggens 'dirty talk'. Samtidig virker de mimetiske fotobidrag som et slags spejl, der forskyder blikretninger og subjekt-objektrelationer, idet læsernes blik på ST's nøgne krop pludselig modsvares. Når alle både kigger på og fremviser sig for alle, bliver både lokaliseringen og karakteren af det implicitte blik mere uklar. Det potentielt begærende blik bliver også et potentielt anerkendende blik, og begxret efter at ville have flyder sammen med begæret efter at ville vare. Den visuelle, kvindekropslige diversitet udgør en decentral materiel situering af bloggens begxr og af dens mange stemmer og erfaringer: Se, det er alle disse kroppe, der spørger og handler, er liderlige, sårbare, skamfulde.

I løbet af de tre år Sugar Tits har eksisteret er en stadig større del af indholdet på bloggen således blevet brugergenereret og værkets gøren i stigende grad relationel. Som bloggens besøgende bliver vi potentielt set medforfattere i dens kollektive hypertekst og aktører i dens online/offline performance. Vi bliver 'the sugar cubes', som ST døber sine mange anonyme læsere og bidragsydere. Gennem spørgefunktionen og de kropslige submissions indvæves også læsernes kroppe som affektive felter i blogkollagens hypertekstuelle netværk. Kollektiviseringen af den intime krop synes netop at være en funktion af blogmediets indbyggede tilskyndelse til at dele. Her bliver oversharing en form for strategi til at overskride den skamfulde, individuelle krop, mens dirty talk i udvidet forstand, kan ses som den performativt diskursive begærsmotor, der binder læserkroppene sammen til 'sugar cubes' og gør Sugar Tits-figuren til en heterogen mangfoldighed, gennemstrømmet af anonyme stemmer og kroppe. Med Braidotti kan man altså sige, at de dialogiske interaktioner og de kropsligt-visuelle 'læseraftryk' både accentuerer "the differences between women" og "the differences within each woman". Ved at sammenvæve en mangfoldighed af kvindelige, kropsliggjorte stemmer, medierer $S u$ gar Tits således den materielle krop som multipel situering og erfaring.

\section{DELTAGELSESFORMER I BLOGGENS BEGIVENHED}

De direkte bidrag og interaktioner via bloggens ask box- og submit-funktioner er imidlertid langt fra den eneste form for participation i Sugar Tits. Så snart vi skriver webadressen i browseren, er vi aktivt perciperende og agerende i bloggens virtuelle rum; scroller op og ned i blogrullen eller klikker os rundt i arkivets hypertekst, lever os ind i spørgernes dilemmaer og forholder os mere eller mindre moralsk eller kønspolitisk til det, der berettes om. Samtidig responderer vi højst sandsynligt affektivt og kropsligt på det eksplicit seksuelle materiale, hvad end det er med ophidselse eller væmmelse. Disse forskellige aspekter af bloglæsernes respons kan beskrives som forskellige participationsformer, der til sammen får bloggen til at virke.

I en dramaturgisk undersøgelse af tilskueren som aktør opstiller teaterteoretikeren Kim Skjoldager-Nielsen en typologi for forskellige niveauer af deltagelse og interaktion, som - de rstetiske og mediemæssige forskelle til trods - kan bruges til at belyseomfanget og virkningen af sexbloggen som kollektiv begivenhed. Skjoldager-Nielsen skelner mellem fem forskellige former for publikumsdeltagelse: Symbolsk/rituel participation, der f.eks. kan findes i det klassiske tragedieteaters inkludering af publikum som symbolske representanter for noget andet, end de er, identifikatorisk participation som, kommer til udtryk i tilskuerens empati med eller psykologiske indlevelse i en karakter, intellektuel participation, der 
beror på kritisk stillingtagen og metarefleksion, som man f.eks. finder det i det absurde teaters Verfremdungsæstetik, performativ participation, hvor realiseringen af selve det dramaturgiske forløb hviler på udførelsen af en bestemt publikumsaktivitet og endelig interaktiv participation, hvor publikum interagerer direkte med skuespillerne og dermed bliver en del af forestillingens fiktive univers (Skjoldager-Nielsen 2008: 47-53). Disse fem former for deltagelse er alle virksomme i Sugar Tits og giver til sammen en god helhedsbeskrivelse af 'blogværket'.

Således kan ST's italesættelse af læserne som "sugar cubes" f.eks. siges at være et eksempel på symbolsk participation. Der er nemlig tale om en billedlig betegnelse, som knyttes til publikum og i den forstand udgør et retorisk-æstetisk greb, der "inkluderer publikum ved at gøre dem til symbol, dvs. et abstrakt tegn, der står i stedet for noget andet" (ibid.: 48). Betegnelsen 'sugar cubes' har hurtigt bidt sig fast som en selvforstærkende markør for det identitetsfællesskab, der er vokset op omkring bloggen og synes i sit billedsprog at samle de individuelle bloglæsere i en kollektiv flerhed, der samtidig knyttes metonymisk til tegnet 'Sugar Tits'. På det symbolske plan deltager blogpublikummet f.eks. som en slags indviede vidner, et kommenterende kor eller "an army of sugar cubes behind you", som en læser formulerer sin opbakning (Sugar Tits, 27.10.2012).

Selve relationen mellem Sugar Tits og 'sugar cubes' etableres til gengxld af den identifikatoriske participation. Det er først og fremmest bloglæsernes identifikation med karakteren Sugar Tits og deres spejling af eget begær, usikkerhed, skam osv. i hendes handlinger og beretninger, der er drivkraft for bloggens performative virkning. Når læserne begynder at bruge forkortelsen WWSD (What Would Sugar Do?) i deres spørgsmål og indbyrdes diskussion af egne livssituationer, bliver den identifikatoriske participations rækkevidde meget konkret samtidig med, at den făr et selvironisk, idoliseret skær. Sugar Tits er ganske vist et alias for et virkeligt menneske, men udgør samtidig en karikeret, semifiktiv figur, der kommer til at fungere ikonisk snarere end psykologisk realistisk.

Netop denne dobbelthed i ST's selviscenesættelse kan siges at tilføje det, Skjoldager-Nielsen kalder intellektuel participation; en form for kritisk metarefleksiv respons ved siden af den umiddelbare, følelsesmæssige indlevelse. I denne sammenhæng synes visse af blogsprogets retoriske virkemidler at have en form for 'Verfremdungseffekt': ST's hyppige anvendelse af citationstegn, tilder og sarkastisk konceptualiserende brug af store begyndelsesbogstaver som f.eks. "the $\sim$ memory of our Weekend Together”, “I'm working on My True Self" etc. virker ikke kun ironisk distancerende, men fremhæver også det konstruerede og normative ved konventionelle romantiske idealer og forståelser af identitet. Med til den intellektuelle participation hører naturligvis også læsernes stillingtagen til de eksplicit køns- og seksualpolitiske udsagn, f.eks. i de rebloggede feministiske citater og i relation til konkrete læserspørgsmål.

Den umiddelbart affektive respons såvel som den ironiske dyrkning og analytiske stillingtagen kan imidlertid ikke adskilles fra den performative og den interaktive participation, som i blogmediet ofte lapper ind over hinanden. Som beskrevet fungerer den interaktive participation via de to knapper "Talk Dirty to Me" og "Submit", hvorigennem læserne stiller spørgsmål og uploader fotografier. Herved interagerer de både direkte med 'karakteren' Sugar Tits og intervenerer i den opførelse som bloggen gestalter. Samtidig udgør de to funktioner også en performativ participation, som med Skjoldager-Nielsens ord er karakteriseret ved, at "publikums udførelse af en bestemt 'gøren' (performativitet) er nødvendig for realisationen af opførelsens dramaturgiske koncept" (ibid.: 48). I bloggens tilfælde 
kan dramaturgien og læsernes 'gøren' siges at have både et online og et offline niveau: På selve bloggen udgør den enkelte postering en begivenhed eller handling, og forløbet dannes af de kontinuerlige publiceringer og dialoger, som netop ikke ville tage form uden læsernes aktive 'gøren' - både i form af deres direkte bidrag til indholdet, men også i form af den dramaturgiske 'rute' gennem hyperteksten, som hver enkelt læser selv skaber med sine klik. Disse online begivenheder er imidlertid samtidig en fortløbende mediering af et parallelt, uafsluttet handlingsforløb offline. Som vist etablerer sexbloggen en konstant gensidig udveksling mellem offline og online, så medieringen ikke blot dokumenterer, men også intervenerer i den fysiske virkelighed. Derfor genererer læsernes virtuelle interaktion med ST og med hinanden også dramaturgiske spor offline $\mathrm{i}$ form af de virkelige, kropslige handlinger og begivenheder, de ansporer. Talrige er de kommentarer f.eks., hvor læsere fortæller om handlinger, som er inspireret af eller endda eksplicit udført med henblik på Sugar Tits og den kollektive reiteration. Således bliver også læsernes fysiske, processuelle kroppe en potentielt aktiv del af bloggens performative og relationelle virkefelt.

\section{SUGAR TITS SOM HYPERVÆRK}

En effekt ved den performative og interaktive participation, hvor publikum - i dette tilfælde bloglæserne - er medskabere af dramaturgien, er ifølge Skjoldager-Nielsen det manglende overblik over "det samlede sceniske landskab”, der gør perceptionen til "en afsøgning af et hypervark vi ikke kan se udkanten af" (Skjoldager-Nielsen: 51). Jeg har i det foregående lavet en afsøgning af nogle forskellige samvirkende elementer og lag i Sugar Tits, der på forskellig vis betinger sexbloggens mediering og aktivering af kroppens materialitet. Bloggens uafgrænsede karakter må forstås i relation til dens udvekslinger mellem offline og online, mel- lem subjekt, krop og medie og som en konsekvens af blogmediets uafsluttede, processuelle karakter. At vi ikke kan se udkanten af Sugar Tits gælder således på alle de tre foregående analyseniveauer: For det første etablerer Sugar Tits' seksuelle performance en konstant vekselvirkning mellem de levende, kropslige begivenheder offline og deres genfortælling online, så de performative interventioner rækker ud over bloggens virtuelle rum. 'Det sceniske landskab' stopper så at sige ikke ved computerskærmen. For det andet udgør selve den interaktive blog en hypertekstuel, multimedial montage af skrift og billeder, som i kraft af læsernes bidrag vokser time for time og skaber et selvsupplerende virtuelt væv af tekst og kropsbilleder. For det tredje skaber 'the sugar cubes' og de mange forskellige participationsformer en uafsluttet kollektiv begivenhed, der finder sted online såvel som offline i et stort, levende netværk af forbindelser og udvekslinger, der også inddrager læsernes fysiske kroppe og handlinger. Til sammen konstituerer disse tre niveauer bloggen som et processuelt, performativt og relationelt hyperværk, der netop virker i kraft af den participerende bloglæsers uafsluttede afsøgning af og (også) kropslige deltagelse i det. Sugar Tits' værkkarakter kan, i lighed med bloggens mediering af kroppen, forstås som en assemblage; en løst sammenholdt flerhed af dele, der til sammen producerer eller synliggør felter af betydning, men som ikke er organisk forbundne i en hierarkisk organiseret struktur.

\section{KROPPEN PÅ BLOGGEN - BLOGGEN SOM KROP}

Med analysen af disse performative, interaktive og participative niveauer af sexbloggens hyperværk kan dens digitalt medierede iværksættelse af kønskroppen gentænkes: Hvor og hvordan er kroppen present i Sugar Tits? Hvilke vilkår giver bloggen som digitalt medie og (sex)blogging som per- 
formativ praksis for at tænke krop og processuel materialitet? Her kan kunsthistorikeren Rune Gades begrebslige tredeling af kropslig (re)præsentation være frugtbar. I sin analyse af performative kunstpraksisser skelner Gade nemlig mellem 'kunsterkroppen', dvs. den private krop bag værket, 'sujet-kroppen', dvs. den krop, der iscenesættes i værket og 'værkets korpus', der er "selve den formmæssige enhed, som udgør værket” (Gade: 44).

I Sugar Tits er det konkrete, materielle afsæt bloggerens egen private 'kunstnerkrop'. Det er ST's kropslige handlinger, funktioner og tilstande, der er omdrejningspunkt for sexhistorierne på bloggen, ligesom den er det materielle, seksuelt stiliserede objekt, vi ser på fotografierne. Disse to elementer - sexbloggens førstepersonsnarrative og visuelle repræsentation af kønskroppen - skaber en spænding mellem kroppen som handlende og sansende subjekt og kroppen som iscenesat objekt. Samtidig synes ST's små her-og-nu-agtige opdateringer og metakommentarer at tilføje et tredje niveau af kropslig mediering på bloggen, nemlig kroppen som det konkrete her og nu, der blogges fra; den fysiske forankring af jeget i bloggens udsigelse. Når f.eks. publiceringen af et billede eller et læsersvar meta-situeres i en aktuel hjemlig situation eller kropslig/affektiv tilstand, præsenteres vi i højere grad for kroppen bag bloggen. Parallelt med den autobiografiske blogs narrative spænding mellem et fortællende jeg og et fortalt jeg er der tale om en 'bloggende krop' bag, eller måske snarere indlejret i 'den bloggede krop'. Denne dobbelte, processuelt konstruerede blogkrop kommer også til syne på det formelle plan; i selve mediets dagbogsagtige organisering af indhold. Her synes den varierende rytme af tidsspecifikke opdateringer at markere en løbende fysisk, kropslig forankring af det virtuelle. ST's egen materielle krop blogges altså ikke kun som 'traditionel' narrativ og visuel representation dvs. som erfaring og morfologisk enhed - men også som en rytme af konkrete situeringer, dvs. som fortløbende, foranderlig kontekst.

Når man så medtænker de interaktive og deltagelsesorienterede aspekter, som jeg har vægtet i det foregående, indtager også læsernes kroppe en tilsvarende sammensat plads i blogkroppen. Med deres spørgsmål, beskrivelser og fotografiske bidrag tilføjer de anonyme 'sugar cubes' en mangfoldighed af kropslig representation $p a ̊$ bloggen og forankring bag bloggen. Bloggens tekstuelle og visuelle kønskrop, såvel som opdateringernes strøm af specifikke kropslige situeringer, multipliceres. Læsernes interaktive og performative deltagelse mangfoldiggør dermed ikke blot de indholdsmæssige repræsentationer af 'kroppen på bloggen' (sujet-kroppen) men også selve den formmæssige struktur, som man kunne kalde 'bloggen som krop' (værkkorpus). Med formationen af 'the sugar cubes' opstår et anonymt kollektiv, der får karakter af en form for intersubjektiv krop - en relationel, polymorf kropslighed, der på det formelle plan spejles i det hypertekstuelle, konstant foranderlige blogkorpus, som læserne afsøger, deltager i og bidrager til.

I forlængelse af Butlers og Braidottis forståelser af kroppen kan man se disse to overordnede niveauer - kroppen på bloggen og bloggen som krop - som en slags dobbelt mediering og aktivering af en processuel kønskrop. Som beskrevet bygger Butlers og Braidottis forståelse af kroppens forandringspotentiale på to forskellige opfattelser af det materielle, som jeg definerede som henholdsvis en performativ og en relationel kropsmaterialitet. Mens det første perspektiv vedrører kroppen som kontinuerligt materialiseret form, tænkes kroppen i det andet som en effekt af vedvarende relationelle udvekslinger. Mens Sugar Tits' sujet-krop ved første øjekast iscenesætter en Butlersk performativ materialitet, der hele tiden er i gang med at blive genfortalt, fremvist, citeret og diskursivt afgrænset, synes Sugar Tits' værkkorpus i stedet at kon- 
struere en relationel, intersubjektiv krop, der i Braidottis optik fungerer som "a transformator of flows and energies, affects, desires, and imaginings" (Braidotti 2011:25). På det ene niveau eksponeres den seksuelle krop som tydeligt stiliseret, kulturelt genkendelig form - f.eks. i Sugar Tits' selvportrætter og interaktionernes eksplicitte italesættelser af kønsorganer og kropsfunktioner. På det andet niveau synes til gengæld en form for opløsning eller overskridelse af den individuelt afgrænsede kønskrop at gøre sig grldende.

Butlers og Braidottis performative og relationelle materialitetsbegreber synes således også at korrespondere med henholdsvis performative og relationelle aspekter i selve blogmediets digitale processer og formsprog: Den omvendte kronologis logik og de stadig fremadskridende, gentagende selvfremførelser og 'live'-opdateringer er netop mediespecifikke vilkår, der understreger blogmediets performative karakter; bloggens citeringsmodus og blogging'ens spænding mellem begivenhed og genfortælling. På den anden side tilfører hypertekstens horisontale, rhizomatiske logik og de digitale interaktioners vidtrækkende karakter blogmediet et relationelt modus. Hermed synes medieringen af Sugar Tits kønnede krop også at udgøre et møde mellem to forskellige processuelle bevægelser; en iterativ, formgivende proces, der, styret af diskurs og normer, stabiliserer kroppens materialitet og gør den seksuelt genkendelig, og simultant, på et andet niveau, en tværgående, mere springende, rhizomatisk, form-opløsende bevægelse, der, bl.a. styret af affektive impulser, relationer og begærsudvekslinger, destabiliserer den afgrænsede, kropslige enhed og lader den overskride sig selv i en affirmativ tilblivelsesproces.

\section{ER SUGAR TITS FEMINISTISK?}

"You still growing out your body hair? Also I love you and am thankful for you every day and think about you whenever I have sex and then wonder how many other people do that too and how many other people also wonder that, meaning that all Sugarcubes think about each other whenever they get down.” (Sugar Tits, 21.02.2012).

Sådan lyder en af de mange kærlighedserklæringer fra en anonym 'sugar cube'. At bloggen har en virkning på sine dedikerede følgere, er der ingen tvivl om. Men kan denne effekt forstås i en kønspolitisk forandringsoptik? Sugar Tits definerer sig selv som feminist, poster jævnligt kønspolitiske citater og fører en løbende samtale på bloggen om emner som f.eks. 'slutsham-ing', 'rape culture' og seksuelle kønsstereotyper.

Alligevel er det ikke på dette pragmatiske, indholdsmæssige plan, at jeg ser bloggens (primære) aktivistiske eller forandringsskabende potentiale.

Som ovenstående citat illustrerer, synes der at være noget andet på spil i Sugar Tits' modus end rationel bevidstgørelse. For både Butler og Braidotti består muligheden for feministisk agens eller forandring primært i ufrivillige processer, som til dels kan udnyttes strategisk. Hos Butler er det kønsperformativitetens tvungne, normciterende gentagelser, der muliggør fejlciteringer og subversive forskydninger. Med Butler kan man således pege på, hvordan Sugar Tits, gennem sine seksualiserede kropsfremførelser, citerer og forskyder f.eks. heteronormative diskurser eller seksuelle kønsstereotyper. I forlængelse af det performative materialitetsbegreb og dets relation til blogkroppen, kan man medtrenke muligheden for, gennem bloggens diskursive praksisser såvel som gennem de kropslige/seksuelle participationsformer, at intervenere performativt $i$ materialiseringen af den kønnede krop.

Alligevel er det som om, Butlers normog diskurskritiske optik ikke helt kan indfange den affirmative, kropslige energi, der (også) produceres i Sugar Tits. Her er det, at Braidottis relationelle materialitetsbegreb og kropslige tilblivelsesprocesser bedre kan bruges til at belyse den form for kropsligt 
funderet, kollektivt transformationspotentiale, der anes i ovenstående citat. Heri illustreres netop den intime og processuelle relation til bloggerens krop ("still growing out your body hair"?) og til de andre læseres kroppe gennem bloggens intersubjektive offline-online værkkorpus. Som vist i analysen opstår denne kollektivisering af det intime netop gennem det digitale medies interaktive, hybride værkkarakter og gennem sexbloggens radikalt kropslige participationsformer. Således synes de nye, digitale medier med deres rhizomatiske og kollektive strukturer at have et potentiale i forhold til at repræsentere, men også aktivt producere kønskropslige forandringsprocesser. Et potentiale der ikke mindst synes væsentligt i diskussioner om den seksuelle og seksualiserede mediekrop: Ved at formidle kroppen som praksis og relation frem for som representation / form eller individuel erfaring indikerer dette perspektiv måske en mulig overskridelse af de subjekt-objektdikotomier og fastlåste seksualpolitiske positioner, der fortsat synes af præge (italesættelsen af) kvindekroppen i medierne. Sugar Tits’ feministiske potentiale ligger således mindst lige så meget i selve bloggens form eller formløshed, dvs. i dens hybride, digitale værkkorpus, som i dens diskursive eller visuelle indhold.

I forlængelse heraf vil jeg til slut foreslå at seSugar Tits som en mulig feministisk figuration. For Braidotti er en figuration en forestillet subjektivitet, der formuleres i en figurligt gestaltet form, og som kan iværksætte kropsligt-affektive tilblivelsesprocesser. Det er en vision, som den enkelte bevæger sig hen imod i både intellektuel og emotionel forstand: "a living map, a transformative account of the self" (Braidotti 2011: 3). Sugar Tits synes netop at virke som et sådan levende, relationelt felt eller kort. Sugar Tits / Sugar Cubes kan forstås som et figurligt, kollektivt, feministisk subjekt, som hver enkelt læser både kan begxre og identificere sig med - og altså potentielt tager kropsligt del $\mathrm{i}$ "whenever they get down".

\section{Noter}

1. Sugar Tits interviewet af Olga Ravn: http://olga-ravn.blogspot.dk/2012/02/its-me-only-faceless-sugar-tits.html

2. Sugar Tits begyndte i juli 2011 som en anonym blog, men i august 2013 stod bloggeren frem som den 25-årige amerikansk-kroatiske modestuderende Thea Hacic-Vlahovic, bosat i Milano. Herefter ændrede bloggen karakter. De personlige sexfortællinger er stort set udgået, ligesom de afklædte, hovedløse selvportrætter, som jeg refererer til. I stedet postes f.eks. klummer skrevet til Vice Magazine, som Hacic-Vlahovic nu skriver fast for. $\mathrm{Si}$ deløbende er der også sket en markant ændring i selve Sugar Tits-karakteren og hendes selvfremstilling. I bloggens to første år er hun single, bor i Milano, arbejder som stripper ved siden af studierne, fester intenst og fremstiller sig selv som promiskuøs og små-alkoholiseret. Efter en længere pause, vender hun i efteråret 2013 tilbage og fortæller, at hun er blevet gift, flyttet tilbage til New York og i gang med at skrive en erindringsbog med titlen "All Sluts Go To Heaven". I denne artikel forholder jeg mig imidlertid primært til bloggen som den så ud og udviklede sig fra juli 2011 til marts 2013.

3. Eroticon i London og Momentum i Washinton, begge holdt første gang afholdt i 2012. Se http://eroticon.writesexright.comog http://momentumcon.com

4. For en diskussion af sexblogging som postfeministisk fænomen i forhold til begreber som seksuel empowerment, seksualisering og "sexual subjectification" (Gill 2003) se Barker \& Gill 2012.

5. Butler og Braidotti repræsenterer to forskellige versioner af poststrukturalistisk feminisme med en række indbyrdes uenigheder, ikke mindst vedr. kønsforskellens ontologiske status og betydning. Selv har de eksplicit kritiseret og kommenteret på hinandens værker (se Braidotti 2002: 39-5 og Butler 2004: 192-204), samt udgivet en lang mailkorrespondance under navnet "Feminism by Any Other Name" (Butler 1994). Det er imidlertid ikke mit ærinde her at diskutere disse uenigheder nærmere, ligesom de bagvedliggende filosofiske paradigmer ligger uden for denne artikels begrænsede omfang. For en mere grundlagsfilosofisk diskussion af performativitetens diskursive gentagelsesmodus overfor tilblivelsens vitalistisk produktive aspekter se f.eks. Mikko Tuhkanen: "Performativity and Becoming" i Cultural Critique 72 / 2009. 6 . Rhizomet - dvs. et horisontalt voksende rodnet med udløbere og sideskud - er et koncept Deleuze og Guattari udvikler i Tusind Plateauer $(2006$ [1980] : 22ff) til at beskrive strukturer og bevæ- 
gelser uden et organiserende centrum eller fast oprindelse. Frem for en linexr eller organisk udviklende bevægelse er den rhizomatiske proces kendetegnet ved vilkårlige forbindelser, midlertidige ansamlinger og pludselige udbrud.

\section{LITTERATUR}

- Attwood, Feona (2009): “Intimate Adventures: Sex Blogs, Sex ‘blooks' and Women's Sexual Narration", i: European Journal of Cultural Studies 2012/9

- Auslander, Philip (2008): Liveness: Performance in a Mediatized Culture, Routledge, London - Barker, Meg \& Gill, Rosalind (2012): "Sexual subjectification and Bitchy Jones's Diary”, i: Psychology and Sexuality, 3/2012

- Braidotti, Rosi (2002): Metamorphoses: Towards a Materialist Theory of Becoming, Polity Press, Cambridge

- Braidotti, Rosi (2011): Nomadic Subjects, Columbia University Press, New York

- Butler, Judith (1993): Bodies that Matter: On the Discursive Limits of "Sex", Routledge, New York

- Butler, Judith (1994): "Feminism by Any Other Name" i Differences 6 /1994

- Butler, Judith (2004): Undoing Gender, Routledge, New York

- Butler, Judith (2007): Gender trouble: Feminism and the subversion of identity. Routledge, New York

. Currier, Dianne (2010): “Assembling bodies in cyberspace" i Pramod K. Nayer (red): The New Media and Cybercultures Anthology", Wiley-

Blackwell

- Damsholt, Tine; Simonsen Gert, Dorthe \& Mordhorst, Camilla (2009): Materialiseringer. Nye Perspektiver på materialitet og kulturanalyse, Aarhus Universitetsforlag

· Downing, Lisa (2012): “Reading Bitchy Jones's Diary: sex blogging, community- building and feminism(s)", i: Psychology \& Sexuality, 3/2012 - Gade, Rune (2005): Konnet i kroppen i kunsten, selvfremstillinger $i$ samtidskunsten, Informations Forlag, København

. Gill, Rosalind (2003): "From sexual objectification to sexual subjectification: The resexualisation of women's bodies in the media" i Feminist Media Studies, 3 / 2003.

- Muise, Amy (2011) : "Women's Sex Blogs: Challenging Dominant Discourses of Heterosexual Desire", i: Feminism \& Psychology 21/2011

- Ray, Audicia (2007) : Naked on the Internet: Hookups, Downloads, and Cashing in on Internet Sexploration, Seal Press

- Schneider, Rebecca (2005): "Solo, Solo, Solo" i Gavin Butt (red): After Criticism: New Responses to Art and Performance, Blackwell Publishing, Oxford

- Skjoldager-Nielsen, Kim (2008): Tilskueren som aktør, Kandidatafhandling ved Teatervidenskab, Københavns Universitet (upubliceret)

- Wood, Elizabeth Anne (2008: "ConsciousnessRaising 2.0: Sex Blogging and the Creation of a Feminist Sex Commons", i: Feminism of Psychology $18 / 2008$ 